\title{
Semiotic Study and Form of Agung Baiturrahim Mosque in Gorontalo City
}

\author{
Muhammad Isla \\ Visual Communication Design and Interior Design \\ Universitas Komputer Indonesia \\ Bandung, Indonesia \\ Muhammadisla07@ email.unikom.ac.id
}

\begin{abstract}
This study aims to examine the semiotics and shape of the Baiturrahim Grand Mosque of Gorontalo City in order to function for the wider community, especially for the authors themselves. This research was written with the descriptive qualitative methods, the writer observed in detail the parts of the mosque and could be obtained from the person who designed the shape of the mosque, and the people associated with the construction of the mosque. The results of this study allow the writer to know and understand the meaning of semiotics and the meaning of the form of the object under study, namely the Baiturrahim grand mosque and get good results both in terms of information and data collection about the object. The results obtained from the authors are quite good because the information is quite clear and access and references from the mosque are quite a lot, and the resource persons from the mosque helped a lot in this research. Conclusion or impact of this research is that the writer, and the public can know the meaning of semiotics and the meaning of the form of the mosque.
\end{abstract}

Keywords - Semiotics and Formation Study, Baiturrahim Great Mosque, Gorontalo City

\section{INTRODUCTION}

A mosque is a place for Muslims to worship and carry out Islamic holidays, in Indonesia there are thousands and even millions of mosques built for Muslims, different forms and models of mosques therefore the authors took the initiative to study one of the mosques in Indonesia precisely in Gorontalo Province [1], Gorontalo City with the aim that writers and the wider community can find out the meaning of semiotics and the form of the mosque because the mosque is one of the icons of Gorontalo City.

The study of semiotics and forms was carried out to find out the meaning of the Baiturrahim grand mosque itself, the meaning of which would benefit the community, especially those in Gorontalo City.

Semiotics offers an approach to research and analyze the system of meaning behind the work and cultural organization [2].Following the synopsis of semiotic theory, this Journal presents data from the ethnosemantic study of Baiturrahim Mosque and shows that in semiotic terms identical code governs people's understanding of the study [3]. The analysis not only shows that semiotic research captures the themes of redun and it is characteristic of insider interpretation of this world of work, but that it is also sensitive to worldly aspects, but critical of a culture. Finally, research shows how semiotic research can explain the rules in which members of the work culture are consistent and coherently produce meaning [4].

The main purpose of this study was to find out the meaning of the form of the Baiturrahim Great Mosque of Gorontalo City so that it could be known by the wider community, especially those in Gorntalo Province itself and more specifically for the authors themselves to become better science developments in the future [5].

\section{METHOD}

This research was written with descriptive qualitative method, the writer observed in detail the parts of the mosque and could be obtained from the person who designed the shape of the mosque and the people associated with the construction of the mosque [6].

\section{RESULTS}

Semiotics means a systematic study of the production and interpretation of signs, how they work, what are the benefits for human life [5]. Semiotics (semiotics) is the science of signs. This science assumes that social / community phenomena and culture are signs. Semiotics studies systems, rules and conventions that allow these signs to have meaning [3]. Semiotics is the science or method of analysis to check signs. A sign is something that represents another that can be in the form of experience, thoughts, feelings, ideas, and so on. So, what can be a real sign is not only language, but various things that surround this life even though it must be admitted that language is the most perfect sign system.

These signs can be in the form of limb movements, eye movements, mouth, writing forms, colors, flags, clothes, artwork, literature, paintings, sculptures, films, dance, music, etc. that are around our lives. The concept of semiotic theory will not be separated from two very instrumental figures in this scientific field, namely Ferdinand de Saussure and Charles Sanders Peirce.

Baiturrahim Great Mosque is one of the old mosques built in the Gorontalo area. The mosque was founded in conjunction with the development of Ohuwato Regency, which 
was recently moved from Dungingi to Gorontalo City, precisely Thursday, 6 Syakban 1140 Hijriah or March 18, 1728 AD by King Botutihe, namely the Head of Batato Government Lo Hulondalo or the Kingdom of Gorontalo at that time.

Baiturrahim Great Mosque was established in the center of the Royal Government (Batato), including Yiladiya (Rumah Raja), Bantayo Poboide (Hall Room / Deliberation Hall), Loji (Apitaluwu residence or Royal Security Officer), and Bele Biya / Bele Tolotuhu, namely the houses of officials kingdom. Furthermore, according to developments

In table 1 describes and shows the ornaments found in the great mosque of Gorontalo City, there are several important ornaments contained in the mosque, the ornaments are constructed in an orderly manner by observing the needs of the worshipers of the mosque.

TABLE I. SPECIFICATIONS OF BAITURRAHIM MOSQUE

\begin{tabular}{|l|l|l|}
\hline \multicolumn{3}{|c|}{ Specifications Mosque } \\
\hline 1 & Tower & A fruit \\
\hline 2 & Mosque capacity & About 3500 worshipers \\
\hline 3 & Broke & $\begin{array}{l}\text { Gorontalo Typical Wood } \\
\text { and deer skin }\end{array}$ \\
\hline 4 & Door & Teak wood \\
\hline 5 & Prayer room & 27X27 Meters \\
\hline
\end{tabular}

Baiturrahim Great Mosque contains many meanings stored in it such as, Qubah which consists of five pieces and is divided into one big qubah and four small qubah containing the meaning of one big qubah signifying the Prophet Muhammad SAW and the four little ones containing the meaning of his companions [6]. Another meaning stored in the mosque is that one tower that has a height of approximately 35 meters has the meaning that Allah and Islam are the one that Muslims must believe in as a way of life to the end of time as for the colors in the Great Mosque Baiturrahim has many colors) [7].

namely that the Gorontalo people are happy with the beauty and every part of the mosque's walls there are many calligraphy writings which have the meaning that Allah is great with all His words [8].

\section{DISCUSSION}

Government and society and Muslims, mosques that previously used wood materials, have been renovated and rebuilt. Among other things, the pillar was replaced with buildings made of stone and walls in $1175 \mathrm{H}$ or $1761 \mathrm{AD}$ by King Unonongo. The wall thickness is 0.80 meters. In 1938 the mosque was destroyed by a devastating earthquake and from that time performing prayers and other services were carried out in emergency buildings near the mosque until 1946. In 1946 and 1947 the rebuilding of the mosque was led by Abdullah Usman as Chair.
In 1964 the Great Mosque of Baiturrahim Gorontalo with a representation of the north and west foyers by a committee led by T. Niode and deputy chairman Haji Yusuf Polapa as daily administrators. In 1969 a new committee was formed again headed by K.O. Naki, B.A. and A. Naue as daily organizer and Kadi Abas Rauf as leader of the Worship. Improvements continued under the leadership of Sun Bone until September 1979. In 1982 there was an additional location for female worshipers in the southern part of the mosque by Mr. Drs. Haji Hasan Abas Nusi, Mayor of Gorontalo City. In 1988, the fence and yard were broadcast by Mr. Drs. Ahmad Najamuddin, Second Level Mayor of Gorontalo District Office . In 1996 the drilling well was used as a place for ablution water and the tower business WANG [9].

Mosque by Mr. Drs. Hai Ahmad Arbie, as the Level II Mayor of Gorontalo. In 1999 and the term of office of the Level II Mayor of Gorontalo, Drs. Hi, Botutihe, the restoration of the Gorontalo City Baiturahim Great Mosque, which was inaugurated by President Bacharuddin Jusuf Habibie at the Merdeka Palace, Wednesday, October 13, 1999 (3 Rajab $1420 \mathrm{H})$.

In Figure 1, the mosque looks from the outside, it can be seen in the picture that the pattern and color of the mosque are typical colors of Gorontalo which are applied to the coloring of this mosque. Also seen is the tower that stands firmly beside the mosque.

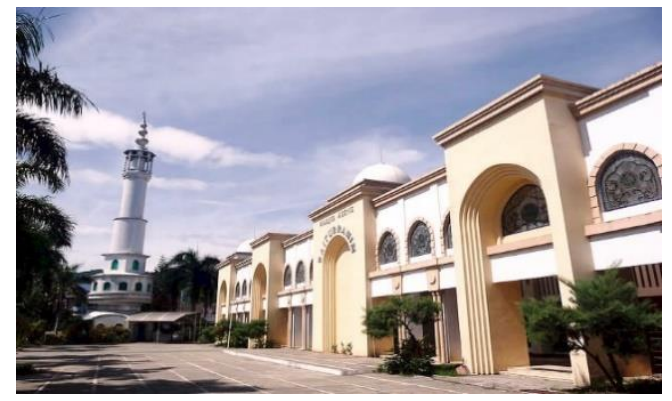

Figure I. Shows A Mosque From Outside

Figure 2 describes the mosque's appearance from within, it can be seen that the ornaments in the mosque are quite a lot because in order for worshipers to perform worship or other religious activities to get comfort while in this mosque, there are also four main pillars located in in the middle of the building that serves as the support of this mosque building 


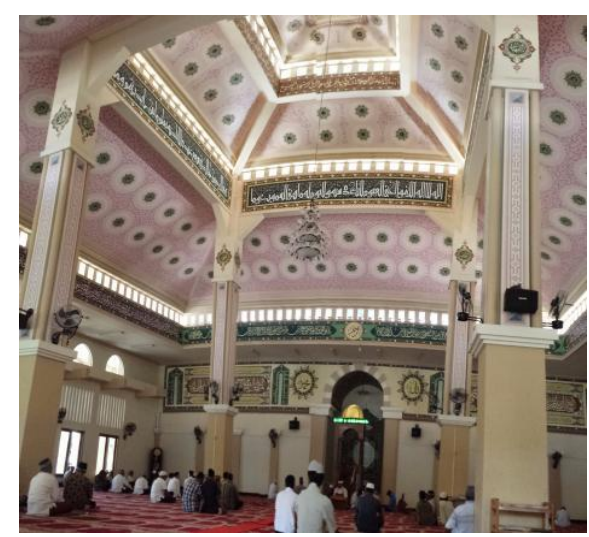

Figure II Shows A Mosque From Inside

\section{CONCLUSION}

Of the several discussions that have been discussed, the authors draw several conclusions including

1. Baiturrahim Great Mosque Gorontalo City is the largest mosque in Gorontalo Province and is a mosque that has a fairly old age and has very much historical value for the people of Gorontalo

2. The process of making a mosque based on the wishes and faith of the community of Pohuwao Regency, this mosque was built as a means of worship for Muslims in the Gorontalo area, especially those in the Pohyuwato district.

3. The meaning of each mosque ornament indicates that this mosque was built with good intentions not just built to show the mosque that was built but pay attention to several aspects.

\section{ACKNOWLEDGMENT}

With the completion of this journal, the author would like to thank God deeply. for the abundance of gifts and guidance so that the author can and complete this journal. Lecturer / mother for guidance, direction and correction during journal preparation and writing. And both of my parents who have helped and supported me in working on this journal.

\section{REFERENCES}

[1] Ayub, Moh, 1996, Mosque Management: Jakarta: Gema Insani Pres.

[2] Joseph, Roger. "The Semiotics of the Islamic Mosque." Arab studies quarterly (1981): 285-295. 2

[3] Pradopo, 2013 study of the theory of Semiotics, Bandung, PT. Teen Rosdakarya

[4] Flood, Finbarr Barry. The Great Mosque of Damascus: Studies on the makings of an Ummayyad visual culture. Vol. 33. Brill, 2001.c

[5] Drs. Alex Sobur, 2006. Communication Semiotics, Bandung, PT. Teen Rosdakarya
[6] Corbin, Juliet, 2009, Basics of Qualitative Research, Yogyakarta: Student Literature.

[7] Netton, Ian Richard. Allah transcendent: Studies in the structure and semiotics of Islamic philosophy, theology and cosmology. Routledge, 2013

[8] Danim, Sudarwan, 2002, Becoming a Qualitative Researcher, Bandung: Faithful Library.

[9] WANG, Ming-yu, and Yao SONG. "The Study of Semiotics in the Last Two Decades in China [J]." Journal of Foreign Languages 1 (2003): 002. 